\title{
Efektivitas Blended Learning Berbasis LMS dengan Model Pembelajaran Inkuiri pada Materi Fluida Statis terhadap Penguasaan Konsep Siswa
}

\author{
Noor Laily Akhmalia ${ }^{{ }^{*}}$, Nengah Maharta ${ }^{2}$, dan Wayan Suana ${ }^{3}$ \\ 1,2,3FKIP FISIKA Universitas Lampung \\ Jl. Prof. Dr. Soemantri Brojonegoro No. 1, Bandar Lampung \\ *E-mail: noorlaily1396@gmail.com
}

\begin{abstract}
Abstrak
Penelitian ini bertujuan untuk mengetahui efektivitas blended learning berbasis LMS dengan model pembelajaran inkuiri terhadap penguasaan konsep siswa. Sampel penelitian ini adalah salah satu SMA Negeri di Bandar Lampung dengan jumlah 68 siswa. Pada kelas eksperimen menggunakan blended learning berbasis LMS dengan model pembelajaran inkuri sedangkan pada kelas kontrol pembelajaran dilakukan dengan metode ceramah (model konvensional). Desain penelitian yang digunakan adalah Pretest-Posttest Control Group Design. Setelah semua data diperoleh data diuji normalitas, homogenitas, dan ancova. Berdasarkan hasil dari uji Ancova nilai $F_{\text {hitung }}>F_{\text {tabel }}(15,45>3,98)$, maka dapat dinyatakan terdapat perbedaan rata-rata penguasaan konsep siswa pada kelas eksperimen dan kelas kontrol artinya blended learning berbasis LMS dengan model pembelajaran inkuiri memberikan pengaruh yang signifikan terhadap penguasaan konsep siswa, serta lebih efektif untuk meningkatkan penguasaan konsep siswa, hal ini ditunjukkan dengan adanya perbedaan rata-rata $\mathrm{N}$-Gain pada kelas eksperimen 0,84 dengan kategori tinggi dan kelas kontrol 0,70 dengan kategori sedang.
\end{abstract}

Kata kunci: Blended Learning, Model Pembelajaran Inkuiri, Penguasaan Konsep

\begin{abstract}
This research was aimed to find out the effectiveness of blended learning on LMS with inquiry learning mode to students concept mastery. The research sample used was 68 students of Senior High School in Bandar Lampung. In experimental class, the researcher used blended learning based on LMS with inquiry learning mode, while in control class the researcher used conventional mode. The research design used was Pretest-Posttest Control Group Design. After all data were collected, the data were tested for normallity, homogeneity, and ancova. Based on the result of ANCOVA with $F_{\text {count }}>F_{\text {table }}(15,45>3,98)$, it shows that there is the difference in the average of students concept mastery in experimental class and control class which means that blended learning based on LMS with inquiry learning mode gives a significant impact to the student concept mastery. In addition, it can effectively enhance the student concept mastery proven by the difference of $\mathrm{N}$-Gain average in experimental class which is 0,84 with the high category and in control class 0,70 with the average category.
\end{abstract}

Keywords: Blended Learning, Inquiry Learning Mode, Concept Mastery.

\section{PENDAHULUAN}

Teknologi informasi pada abad 21 berkembang dengan sangat pesat. Hal ini menyebabkan terjadinya perubahan dalam dunia pendidikan, dalam menghadapi perubahan tersebut peserta didik dituntut untuk memiliki keterampilan berpikir yang kritis, pengetahuan dan kemampuan literasi digital, literasi informasi, dan literasi media serta menguasai teknologi informasi dan komunikasi (Frydenberg \& Andone, 2011). Oleh karena itu, agar pembelajaran pada abad 21 sukses guru harus merancang desain pembelajaran yang mampu memuat keterampilan pada abad 21. Hal yang dapat dilakukan yaitu menerapkan penggunaan internet dalam pembelajaran dimana menurut Trilling \& Fadel (2009: 50) penggunaan internet dalam pembelajaran mampu mengembangkan kemampuan siswa dalam keterampilan teknologi dan media informasi.

Kenyataannya masih banyak desain pembelajaran yang diterapkan oleh guru tidak memuat keterampilan pada abad 21 , contohnya di salah satu SMA Negeri di Bandarlampung. 
Berdasarkan hasil wawancara dengan salah satu guru kelas XI SMA Negeri di Bandarlampung dalam pembelajaran guru fisika menggunakan metode ceramah sehingga pembelajaran fisika lebih berpusat pada guru (teacher centered), ketika menggunakan metode ceramah dalam pembelajaran fisika pada materi fluida statis siswa mengalami kesulitan dalam belajar, penggunaan metode ceramah menurut guru kurang meningkatkan penguasaan konsep siswa, guru mengalami kekurangan waktu dalam pembelajaran.

Pemaparan di atas menunjukkan bahwa desain pembelajaran dengan metode ceramah kurang efektif jika diterapkan dalam materi fluida statis. Oleh karena itu, guru harus memilih model pembelajaran yang cocok dengan materi fluida statis. Model pembelajaran yang digunakan pada materi fluida statis harus mampu mengatasi kesulitan-kesulitan siswa sehingga siswa memiliki pemahaman konsep yang baik. Salah satu model pembelajaran yang dapat diterapkan dalam materi fluida statis adalah model pembelajaran inkuiri.

Model pembelajaran inkuri menurut Eggen dalam Sinuraya dkk., (2012: 73) adalah model pembelajaran yang disusun untuk melatih siswa menyelidiki masalah-masalah dan pemecahannya berdasarkan fakta. Penerapan model pembelajaran inkuiri dalam pembelajaran juga sesuai dengan tuntutan kompetensi abad 21, seperti berpikir kritis, kemampuan pemecahan masalah, dan berkomunikasi efektif (King \& Arnold, 2012). Pada penelitian ini model pembelajaran yang diterapkan adalah inkuiri terbimbing. Hasil penelitian mengenai model pembelajaran inkuiri, yaitu Penelitian oleh Bulan dkk., (2015) menunjukkan bahwa kemampuan inkuiri berpengaruh terhadap hasil belajar fisika dengan bantuan virtual laboratory dan terdapat peningkatan yang signifikan pada hasil belajar fisika. Penelitian Winanti dkk., (2015) bahwa model pembeljaran inkuiri dengan pendekatan nilai memberikan pengaruh yang lebih baik terhadap hasil belajar siswa dan sikap positif siwa

Model pembelajaran inkuiri memiliki kelemahan, yaitu keterbatasan waktu, sehingga menyebabkan tahapan pembelajaran belum selesai dilaksanakan sementara waktu sudah habis (Sinuraya dkk., 2012: 73). Salah satu upaya untuk mengatasi kurangnya waktu dalam pembelajaran, meningkatkan keterampilan teknologi, meningkatkan pemahaman konsep siswa pada materi fluida statis adalah dengan cara menerapkan sistem blended learning dalam proses pembelajaran.

Blended learning menurut Rovai \& Jordan (2004: 3) adalah gabungan keunggulan pembelajaran dimana dilakukan secara tatap muka (face-to-face learning) dan secara virtual (e-learning). Jadi, pembelajaran fluida statis akan dilakukan dengan menggabungkan pembelajaran secara tatap muka dan online learning. Pada penelitian ini tipe blended learning yang digunakan yaitu, tipe online-tatap muka. Pada kelas online dilakukan beberapa kegiatan proses inkuiri dimana siswa diberikan fenomena kemudian siswa dituntut untuk membuat rumusan masalah dan hipotesis mengenai fenomena tersebut, merancang percobaan dan mendiskusikannya bersama secara online, sedangkan pada pembelajaran tatap muka siswa melanjutkan kegiatan inkuiri, yaitu melakukan percobaan, mengumpulkan dan menganalisis data tersebut, serta membuat kesimpulan.

Beberapa penelitan mengungkapkan bahwa terdapat pengaruh dari penerapan blended learning, yaitu penelitian yang dilakukan oleh Azizah dkk., (2017) bahwa terdapat pengaruh pembelajaran e-learning dengan schoology terhadap hasil belajar siswa yang ditunjukkan dengan $N$-Gain 0,619 , yaitu pada kategori sedang. Selain itu, penelitian dari Awodeyi dkk., (2014) mengungkapkan bahwa dengan menggunakan pendekatan blended learning dapat meningkatkan nilai prestasi siswa dibandingkan dengan pendekatan lainnya. Penelitian dari Hermawanto (2013: 75) menunjukkan bahwa penguasaan konsep fisika peserta didik yang belajar menggunakan blended learning lebih tinggi dibandingkan penguasaan konsep fisika peserta didik yang belajar tanpa menggunakan blended learning. Penelitian Lin dkk., (2017: 765) menunjukkan bahwa penerapan dari blended learning menunjukkan pengaruh yang signifikan terhadap prestasi akademik siswa, nilai posttest menunjukkan bahwa nilai kelompok eksperimen meningkat secara signifikan dibandingkan nilai kelompok kontrol.

Penerapan blended learning memerlukan learning management system (LMS). Mahnegar (2012) berpendapat bahwa Learning Management 
System (LMS) merupakan suatu aplikasi atau software yang digunakan untuk mengelola pembelajaran online baik dari segi materi, penempatan, pengelolaan, dan penilaian. Salah satu LMS yang digunakan saat ini adalah schoology. Schoology menurut Putri dkk., (2014) adalah website yang memadu e-learning dan jejaring sosial, sehingga mudah digunakan karena seperti media sosial Facebook, serta menawarkan pembelajaran yang sama seperti dikelas secara gratis.

Hasil penelitian mengenai schoology yang dilakukan oleh Hasanah dkk., (2016) bahwa pembelajaran e-Learning dengan schoology efektif untuk digunakan sebagai suplemen pembelajaran karena 91\% siswa mencapai KKM untuk aspek kognitif dan 100\% siswa mencapai KKM untuk aspek afektif dan psikomotor.

Penguasaan konsep siswa pada penelitian ini diukur dengan menggunakan instrumen soal pilihan ganda dimana soal tersebut terdiri dari enam dimensi aspek kognitif yang diduga dapat meningkat dengan blended learning, yaitu mengingat (C1), memahami (C2), mengaplikasikan (C3), dan menganalisis (C4), mengevaluasi (C5), dan mencipta (C6).

Berdasarkan pemaparan di atas terkait pentingnya siswa memiliki keterampilan pada abad 21 , kesulitan siswa dalam memahami pembelajaran fluida statis, keterbatasan waktu pembelajaran dalam materi fluida statis, maka peneliti telah melakukan penelitian eksperimen dengan judul "Efektivitas blended learning berbasis $L M S$ dengan model pembelajaran inkuiri pada materi fluida statis terhadap penguasaan konsep siswa".

\section{METODE}

Penelitian ini merupakan penelitian eksperimen dengan metode quasy experimental dengan jenis pretest-posttest group design. Desain penelitian dapat dilihat pada Tabel 1 .

Tabel 1. Desain Penelitian

\begin{tabular}{lcccc}
\hline Kelas & $\begin{array}{c}\text { Pre- } \\
\text { test }\end{array}$ & \multicolumn{2}{c}{$\begin{array}{l}\text { Perla- } \\
\text { Kuan }\end{array}$} & \multicolumn{2}{c}{$\begin{array}{l}\text { Post- } \\
\text { tes }\end{array}$} \\
\hline Eksperimen & $\mathrm{O}_{1}$ & $\mathrm{X}_{1}$ & $\mathrm{O}_{2}$ \\
Kontrol & $\mathrm{O}_{3}$ & $\mathrm{X}_{2}$ & $\mathrm{O}_{4}$ \\
\hline
\end{tabular}

Desain penelitian menggunakan dua kelas, yaitu kelas eksperimen dan kelas kontrol. Perlakuan yang diberikan pada kelas eksperimen, adalah blended learning bebasis LMS dengan model pembelajaran inkuiri $\left(X_{1}\right)$ dan pada kelas kontrol, yaitu model pembelajaran konvensional $\left(X_{2}\right)$.

Populasi penelitian ini adalah seluruh siswa kelas XI SMA Negeri 16 Bandarlampung pada semester genap tahun ajaran 2017/2018 dengan jumlah siswa 165 siswa, sedangkan sampel penelitian yang diambil, yaitu kelas XI IPA $A_{5}$ sebagai kelas eksperimen dan XI IPA 4 sebagai kelas kontrol yang berjumlah 68 siswa. Sampel penelitian dilakukan dengan teknik random sampling in class, yaitu dengan cara diundi.

Variabel bebas pada penelitian ini adalah blended learning berbasis LMS dengan model pembe-lajaran inkuiri, sedangkan variabel terikat adalah penguasaan konsep siswa. Instrumen yang digunakan dalam penelitian ini berupa Silabus, Rencana Pelaksanaan Pembelajaran (RPP), Lembar Kerja Peserta Didik (LKPD), handout, schoology sebagai pendukung blended learning, dan tes berupa soal pilihan ganda dimana memuat tiap indikator kognitif siswa yang digunakan saat pretest dan posttest.

Data yang diperoleh pada penelitian ini, yaitu penguasaan konsep siswa pada ranah kognitif. Setelah data diperoleh, maka dilakukan uji analisis data berupa uji $\mathrm{N}$-Gain. Kemudian uji normalitas dengan Kolmogrov-Smirnov yang bertujuan untuk mengetahui data yang diperoleh berdistribusi normal atau tidak, dengan pengambilan keputusan jika nilai signifikansi $>0,05$ data terdistribusi normal dan nilai signifikansi $\leq 0,05$ data tidak terdistribusi normal. Selanjutnya uji homogenitas yang bertujuan untuk mengetahui varian dalam populasi tersebut homogen atau tidak, jika signifikansi $>0,05$ data homogen dan nilai signifikansi $\leq 0,05$ data tidak homogen. Terakhir, yaitu uji analysis of covariance (Ancova) untuk mengetahui apakah hipotesis dapat diterima atau ditolak, dengan pengambilan keputusann jika $\mathrm{F}_{\text {hitung }}>\mathrm{F}_{\text {tabel }}$ maka $\mathrm{H}_{\mathrm{o}}$ ditolak dan $\mathrm{H}_{1}$ diterima.

Penelitian ini menerapkan blended learning berbasis inkuiri dimana dilakukan pembelajaran secara online menggunakan schoology dan pembelajaran secara tatap muka. Online learning dilakukan sebanyak 4 kali sesuai topik materi yang akan disampaikan yaitu tekanan hidrostatis, hukum Pascal, hukum Archimedes, dan gejala meniskus 
serta dilaksanakan sebelum pembelajaran secara tatap muka berlangsung. Pada saat online learning siswa melaksanakan kegiatan inkuiri secara individu dan diskusi kelompok, yaitu siswa akan diberikan fenomena, membuat rumusan masalah, hipotesis, dan merancang percobaan, kemudian siswa mengupload jawaban individu dan kelompok mereka ke dalam course fluida statis pada schoology dengan batas waktu tertentu serta melanjutkan diskusi pada schoology. Setelah siswa mengikuti online learning, pembelajaran dilanjutkan secara tatap muka.

\section{HASIL DAN PEMBAHASAN}

\section{HASIL}

Proses pembelajaran pada penelitian ini dilakukan sebanyak enam pertemuan, dimana pada pertemuan ke-1 dilakukan pretest, pertemuan ke-2 dan ke-5 dilaksanakan pembelajaran, pertemuan ke-6 dilakukan posttest. Pada kelas eksperimen diterapkan blended learning berbasi LMS dengan model pembelajaran inkuiri, dimana sebelum melaksanakan pembelajaran tatap muka dengan guru siswa sudah melaksanakan online learning terlebih dahulu di schoology. Pada kegiatan online learning semua siswa mengupload dengan jumlah post pada kegiatan online learning ke-1 sebanyak 173 post (dilaksanakan sebelum pertemuan ke-2), kegiatan online learning ke-2 sebanyak 145 post (dilaksanakan sebelum pertemuan ke-3), kegiatan online learning ke-3 sebanyak 172 post (dilaksanakan sebelum pertemuan ke-4), dan kegiatan online learning ke-4 sebanyak 119 post (dilaksanakan sebelum pertemuan ke-5). Setelah siswa mengikuti online learning, pembelajaran dilanjutkan secara tatap muka, sedangkan pada kelas kontrol diterapkan model pembelajaran konvensional.

Sebelum melakukan penelitian, soal terlebih dahulu diuji validitas dan reliabilitas dimana bertujuan untuk mengetahui kelayakan instrumen soal tersebut untuk digunakan dalam penelitian. Uji ini dilakukan pada siswa kelas XII yang berjumlah 60 siswa, yang telah belajar mengenai Fluida Statis dengan jumlah 36 soal. Setelah dilakukan uji validitas dan reliabilita, diketahui bahwa jumlah soal yang dinyatakan valid, yaitu 36 soal dan data hasil uji reliabilitas menunjukkan nilai cronbach's alpha sebesar 0,794 yang artinya soal bersifat reliabel.

Tabel 2. Data Rata-rata Hasil Pretest Siswa

\begin{tabular}{cccc}
\hline No & Parameter & $\begin{array}{c}\text { Pretest } \\
\text { Kelas } \\
\text { Eksperimen }\end{array}$ & $\begin{array}{c}\text { Pretest } \\
\text { Kelas } \\
\text { Kontrol }\end{array}$ \\
\hline 1 & Jumlah siswa & 33 & 35 \\
2 & Nilai terendah & 25 & 25 \\
3 & Nilai tertinggi & 47 & 50 \\
4 & Rata-rata nilai & 37,12 & 36,90 \\
\hline
\end{tabular}

Berdasarkan pada Tabel 2, rata-rata nilai pretest kelas eksperimen lebih besar dari rata-rata nilai pretest kelas kontrol. Namun, tidak ada perbedaan yang signifikan antara nilai pretest kelas eksperimen dengan nilai pretest kelas kontrol, artinya kelas eksperimen dan kelas kontrol memiliki kemampuan penguasaan konsep yang sama.

Tabel 3. Data Rata-rata Hasil Posttest Siswa

\begin{tabular}{llcc}
\hline No & Parameter & $\begin{array}{c}\text { Posttest } \\
\text { Kelas } \\
\text { Eksperimen }\end{array}$ & $\begin{array}{c}\text { Posttest } \\
\text { Kelas } \\
\text { Kontrol }\end{array}$ \\
\hline 1 & Jumlah siswa & 33 & 35 \\
2 & Nilai terendah & 81 & 69 \\
3 & Nilai tertinggi & 97 & 92 \\
4 & Rata-rata nilai & 89,98 & 81,50 \\
\hline
\end{tabular}

Berdasarkan pada Tabel 3, rata-rata nilai posttest kelas eksperimen lebih besar dari pada rata-rata nilai posttest kelas kontrol. Grafik perolehan nilai rata-rata penguasaan konsep siswa dapat dilihat pada Gambar 1.

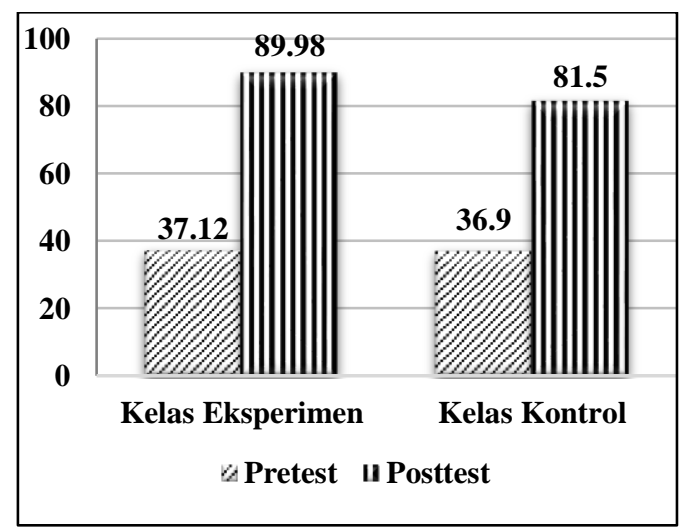

Gambar 1. Rata-rata Penguasaan Konsep Fluida Statis Siswa 
Tabel 4. Data Rata-rata N-Gain Penguasaan Konsep Fluida Statis Siswa

\begin{tabular}{llcc}
\hline No & Perolehan Skor & $\begin{array}{c}\text { Kelas } \\
\text { Eksperimen }\end{array}$ & $\begin{array}{c}\text { Kelas } \\
\text { Kontrol }\end{array}$ \\
\hline 1 & Gain Tertinggi & 67 & 61 \\
2 & Gain Terendah & 39 & 25 \\
3 & Rata-rata Gain & 53 & 45 \\
4 & Kenaikan skor & $53 \%$ & $45 \%$ \\
& rata-rata & 0,84 & 0,70 \\
5 & Rata-rata N-Gain & Tinggi & Sedang \\
6 & Kategori & & \\
\hline
\end{tabular}

Berdasarkan pada Tabel 4, nilai rata-rata $N$ Gain kelas eksperimen lebih tinggi dari rata-rata $N$ Gain kelas kontrol. Grafik perolehan nilai rata-rata $N$-Gain penguasaan konsep siswa disajikan pada Gambar 2 dan Gambar 3.

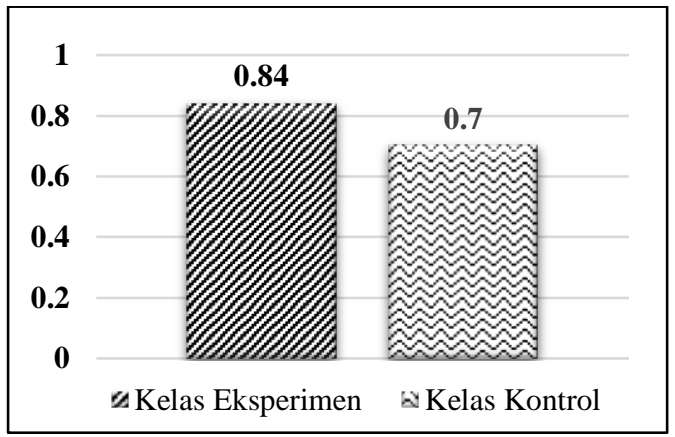

Gambar 2. Rata-rata N-Gain

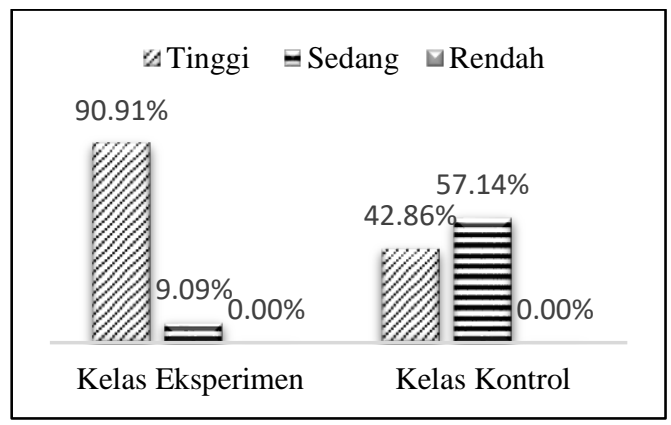

Gambar 3. Kategori N-Gain

Berdasarkan Tabel 5, persentase N-Gain dengan kategori tinggi pada kelas eksperimen lebih besar dari pada persentase $N$-Gain kelas kontrol.

Setelah mendapatkan nilai $\mathrm{N}$-Gain selanjutnya dilakukan uji normalitas. Berdasarkan Tabel 6, dapat diketahui bahwa nilai Asymp. Sig (2tailed) $\mathrm{N}$-gain pada kelas eksperimen adalah 0,631 sedangkan nilai Asymp. Sig (2-tailed) N-gain pada kelas kontrol adalah 0,891, dimana nilai Asymp. Sig (2-tailed) $\mathrm{N}$-gain pada kelas eksperimen dan kelas kontrol lebih dari 0,05 sehingga data $\mathrm{N}$-gain pada kelas eksperimen dan kelas kontrol berdistribusi normal.

Setelah dilakukan uji normalitas kemudian dilakukan uji homogenitas dimana berdasarkan Tabel 7, dapat diketahui bahwa nilai sig. 0,063, karena signifikasi lebih dari 0,05 maka dapat disimpulkan bahwa kedua kelompok data (data kelas eksperimen dan kelas kontrol) mempunyai varian yang sama.

Berdasarkan Tabel 8, uji ancova pretest dan posttest penguasaan konsep siswa dapat dinyatakan bahwa nilai $F_{\text {hitung }}>F_{\text {tabel }}(15,49>3,98)$ maka $\mathrm{H}_{0}$ ditolak dan $\mathrm{H}_{1}$ diterima, berarti terdapat perbedaan rata-rata penguasaan konsep siswa pada kelas eksperimen dan kelas kontrol, artinya blended learning berbasis inkuiri memberikan pengaruh yang signifikan terhadap penguasaan konsep siswa pada materi fluida statis.

Tabel 5. Data Kategori $N$-Gain Penguasaan Konsep Siswa

\begin{tabular}{ccccc}
\hline \multirow{2}{*}{ Kategori } & \multicolumn{2}{c}{ Kelas Eksperimen } & \multicolumn{2}{c}{ Kelas Kontrol } \\
\cline { 2 - 5 } & Jumlah & Persentase & Jumlah & Persentase \\
\hline Tinggi & 30 & $90,91 \%$ & 15 & $42,86 \%$ \\
Sedang & 3 & $9,09 \%$ & 20 & $57,14 \%$ \\
Rendah & 0 & $0,00 \%$ & 0 & $0,00 \%$ \\
\hline
\end{tabular}

Tabel 6. Hasil Uji Normalitas Skor N-Gain Penguasaan Konsep Siswa

\begin{tabular}{llcccc}
\hline \multirow{2}{*}{ No } & \multirow{2}{*}{ Parameter } & \multicolumn{2}{c}{ Kelas Eksperimen } & \multicolumn{2}{c}{ Kelas Kontrol } \\
\cline { 3 - 6 } & & Pretest & Posttest & Pretest & Posttest \\
\hline 1. & Jumlah Siswa & 33 & 33 & 35 & 35 \\
2. & Rata-rata & 37,12 & 89,98 & 36,90 & 81,50 \\
3. & Nilai Tertinggi & 47 & 97 & 50 & 92 \\
4. & Nilai Terendah & 25 & 81 & 25 & 69 \\
5. & N-gain & \multicolumn{2}{c}{0,84} & & 0,70 \\
6. & Asymp. Sig (2-tailed) & \multicolumn{2}{c}{0,631} & & 0,891 \\
\hline
\end{tabular}

Tabel 7. Hasil Uji Homogenitas N-Gain Penguasaan Konsep Siswa

\begin{tabular}{llll}
\hline Levene Statistic & $d f 1$ & $d f 2$ & Sig. \\
\hline 1,375 & 1 & 66 & 0.063 \\
\hline
\end{tabular}

Tabel 8. Hasil Uji Ancova Penguasaan Konsep Siswa

\begin{tabular}{llllll}
\hline Kelas & $N$ & mean & S.D & Std. error & $F$ \\
\hline Kelas eksperimen & 33 & 89,84 & 4,84 & 1,06 & 15,45 \\
Kelas Kontrol & 35 & 81,57 & 7,06 & 1,03 & \\
\hline
\end{tabular}

\section{PEMBAHASAN}

Hasil analisis terhadap nilai rata-rata pretest, 
yaitu pada kelas eksperimen sebesar 37,12 sedangkan pada kelas kontrol sebesar 36,9. Nilai rata-rata posttest pada kelas eksperimen sebesar 89,98 , sedangkan pada kelas kontrol sebesar menjadi 81,5 , sehingga peningkatan rata-rata penguasaan konsep siswa pada kelas eksperimen sebe-sar 52,86 dan pada kelas kontrol sebesar 44,60 , sehingga dapat disimpulkan bahwa peningkatan rata-rata kelas eksperimen lebih besar dibandingkan kelas kontrol.

Berdasarkan Gambar 8, pada ke-las eksperimen siswa dengan kategori $N$-Gain tinggi sebanyak 30 siswa $(90,91 \%)$, kategori sedang 3 siswa $(9,09 \%)$, dan kategori rendah sebanyak 0 siswa $(0,00 \%)$. Pada kelas kontrol siswa yang memperoleh $\mathrm{N}$-Gain dengan kategori tinggi sebanyak 15 siswa $(42,86 \%)$, kategori sedang sebanyak 20 siswa (57,14\%), dan kategori rendah sebanyak 0 siswa $(0,00 \%)$.

Hasil analisis pada Ancova dapat disimpulkan bahwa terdapat perbedaan rata-rata penguasaan konsep siswa antara kelas eksperimen dengan kelas kontrol, artinya terdapat pengaruh yang signifikan dari blended learning berbasis $L M S$ dengan model pembelajaran inkuri terhadap penguasaan konsep siswa pada materi fluida statis. Hal ini terlihat $F_{\text {hitung }}>F_{\text {tabel }}(15,45>3,98)$ maka $\mathrm{H}_{0}$ ditolak dan $\mathrm{H}_{1}$ diterima, perbedaan ini disebabkan oleh perbedaan perlakuan pada proses pembelajaran dimana pada kelas eksperimen proses pembelajaran menggunakan blended learning ber-basis LMS dengan model pembelajaran inkuiri sedangkan pada kelas kontrol menggunakan pembelajaran kovensional (metode ceramah). Jadi, blended learning berbasis LMS dengan model pembelajaran inkuiri lebih efektif dibandingkan pembelajaran konvensional (metode ceramah), hal ini dilihat dari hasil perhitungan $N$ Gain kelas eksperimen sebesar 0,84 dengan kategori tinggi, sedangkan pada kelas kontrol ratarata $\mathrm{N}$-Gain penguasaan konsep siswa sebesar 0,70 dengan kategori sedang.

Penelitian ini juga mengacu pada teori belajar yang mendukung blended learning berbasis LMS dengan model pembelajaran inkuiri untuk meningkatkan penguasaan konsep siswa, yaitu teori belajar konstruktivisme (individual learning) dari Piaget, pendekatan konflik kognitif, dan lingkungan belajar sosial atau sosial kontruktivis (callaborative learning) dari Vygotksy.

Pada teori belajar kontruktivisme, siswa mengkonstruksi pengetahuan mereka di atas pengetahuan awal yang telah diperoleh sebelumnya, siswa aktif dalam melakukan kegiatan dan aktif berfikir (Wicaksono dan Roza, 2015: 422). Berdasarkan pemaparan di atas mengenai teori konstruktivisme, pada saat blended learning siswa membangun pengetahuan mereka sendiri berdasarkan pengetahuan awal yang diperoleh ketika online learning, kemudian pada saat face-toface learning siswa melakukan kegiatan dan aktif berpikir dengan membandingkan pengetahuan yang telah dimiliki dengan pengetahuan baru yang sedang dipelajari secara experimental learning, sehingga siswa dapat membangun pengetahuannya sendiri, memiliki kemampuan berpikir yang lebih aktif dan kreatif, mampu menyelesaikan setiap persoalan, serta pembelajaran akan lebih bermakna. Pendekatan konflik kognitif pada penelitian ini terjadi ketika online learning siswa disajikan beberapa permasalahan sehingga siswa mengalami proses asimilasi yaitu siswa menggunakan konsep yang dimilikinya dalam penyelesaian masalah baru, kemudian guru memberikan penyelesaian masalah tersebut dengan tepat ketika face-to-face learning sehingga siswa mengalami proses akomodasi yaitu siswa tidak menggunakan konsep yang dimiliki karena tidak sesuai dengan permasalahan baru yang mereka hadapi.

Selanjutnya teori belajar konstruktivisme sosial (Callaborative Learning) yang dikembangkan oleh Vygotsky. Teori konstruktivisme (individual learning) Piaget menjelaskan bahwa pengetahuan diperoleh seorang anak merupakan hasil dari konstruksi pengetahuan awal yang telah dimiliki dengan pengetahuan yang baru diperolehnya (Ummi \& Mulyaningsih, 2016: 43). Pada penelitian ini kaitan blended learning berbasis LMS dengan model pembelajaran inkuri dengan teori konstruktivisme sosial yaitu ketika pembelajaran terjadi interaksi sosial ketika online learning dimana mereka berdiskusi mengenai materi melalui schoology dan ketika face-to-face learning siswa melakukan experimental learning bersama dengan kelompoknya.

Hal ini menyebabkan siswa mampu berinteraksi, bertukar gagasan, mengkonstruksi 
pengetahuan melalui interaksi sosial dengan anggota kelompok mereka atau orang lain, siswa yang belum jelas akan suatu permasalahan akan bertanya dengan teman satu kelompoknya yang dirasa sudah memahami suatu konsep, sehingga membuat siswa mudah memahami suatu konsep serta memiliki penguasaan konsep yang baik, dalam hal ini guru harus selalu siap menjadi fasilitator untuk siswa.

Pembelajaran blended learning ini memiliki keunggulan yaitu memberikan minat belajar mandiri siswa karena banyak informasi yang dapat diperoleh melalui internet, bisa mengakses materi yang diberikan secara online dimanapun siswa berada secara mudah baik dengan e-learning online, e-learning offlliner, dan pemanfaatan teknologi mobile (mobile learning) tanpa batasan ruang dan waktu dengan pembelajaran tatap muka (face-to-face learning) memungkinkan untuk melakukan pembejaran secara interaktif sehingga proses pembelajaran akan berjalan dengan optimal karena kelebihan dari kedua model tersebut akan dapat saling melengkapi dari masing-masing kekurangan kedua model pembe-lajaran tersebut, meningkatkan penguasaan konsep siswa, meningkatan interaksi antara guru dengan siswa, serta meningkatkan kemampuan literisasi informasi dan literisasi TIK siswa, hal ini sejalan dengan pendapat Bawaneh (2011) menyatakan bahwa blended learning dapat meningkatkan performansi siswa yang dapat dilihat dari meningkatnya jumlah peserta didik yang online dalam pembelajaran dan melakukan diskusi online, menurut Mubaraq dalam Hermawanto (2013) menyatakan pembelajaran berbasis web mampu menumbuhkan kemandirian siswa untuk mengkostruksi sendiri pengetahuannya yang ditujukkannya dengan peningkatan penguasaan konsep, peningkatan generik sains, dan siswa memberikan tanggapan yang baik.

Model pembelajarann inkuiri sendiri mampu meningkatkan pengusaan konsep siswa, hal ini dikarenakan pembelajaran inkuiri memberikan peluang kepada siswa menjadi lebih aktif ketika pembelajaran dikarenakan selama pembelajaran banyak melakukan diskusi baik ketika online learning dan face-to-face learning, ketika pembelajaran siswa melakukan kegiatan dimana mereka mengembangkan pengetahuan dan pemahaman mengenai ide-ide ilmiah, model pembelajaran inkuiri dalam jangka waktu tertentu dapat memberikan kemampuan kepada siswa untuk mengumpulkan ide-ide, mencari bukti untuk mendukung ide-ide, menggunakan dan mengembangkan keterampilan mengumpulkan data, bekerja secara kolaboratif dengan orang lain, serta siswa kritis terhadap proses dan hasil dari investigasi mereka.

Penggunaan model inkuiri dapat meningkatkan penguasaan konsep siswa didukung penelitian oleh Sakdiah (2018) Nilai rata-rata pretest siswa kelas eksperimen dan kelas kontrol berturut-turut 20 dan 21 sedangkan nilai posttest kelas eksperimen 76 dan posttest kelas kontrol 72 , sehingga peningkatan pemahaman konsep dan KPS kelas eksperimen lebih tinggi dibandingkan dengan kelas kontrol jadi dapat disimpulkan bahwa model inkuiri terbimbing berdampak positif untuk meningkatkan pemahaman konsep dan KPS siswa SMP pada materi listrik dinamis. Penelitian Azizmalayeri dkk., (2012: 1) menyebutkan bahwa penggunaan model pembelajaran inkuiri dapat meningkatkan pemahaman sains, prestasi akademik, kemampuan berpikir kritis dan keterampilan membuat prediksi. Serta penelitian dari Ergul, dkk (2011) yang menunjukkan bahwa pembelajaran degan model pembelajaran inkuiri dapat meningkatkan keterampilan proses dan penguasaan konsep siswa.

Blended Learning mampu mendukung peningkatan self regulated learning terhadap siswa, hal ini sejalan dengan penelitian oleh Lynch \& Dembo (2004) bahwa blended learning efektif mendukung adanya peningkatan terhadap self regulated learning siswa. Penelitian oleh Sutisna (2016) menunjukkan bahwa penerapan blended learning mampu meningkatkan kemandirian belajar peserta didik program paket C PKBM sebanyak $48,2 \%$. Self regulated learning memiliki pengaruh terhadap prestasi akademik siswa, semakin tinggi tingkat self regulated learning yang dimiliki oleh siswa semakin tinggi prestasi akademiknya, hal ini sejalan dengan penelitian Novitayati (2013) bahwa blended learning mampu meningkatkan self regulated siswa dan pada akhirnya mampu meningkakan hasil belajar kognitis siswa.

Pembelajarann blended learning juga mampu meningkatkan penguasaan konsep siswa, hal ini sejalan dengan penelitian Hermawanto (2013: 75) bahwa didapatkan nilai $Q_{\text {hitung }}>Q_{\text {tabel }}(7,55>2,85)$ yang menunjukkan penguasaan konsep siswa yang 
menggunakan blended learning lebih tinggi dari pada konvensinal. Selain itu, penelitian dari Nazarenko (2015: 81) menunjukkan bahwa $60 \%$ siswa menyukai belajar dengan cara blended learning karena belajar secara blended learning memudahkan siswa dalam mengakses materi pelajaran, meningkatkan keterampilan siswa, dan memotivasi siswa untuk menggunakan TIK secara maksimal. Selanjutnya, penelitian oleh Heinze (2008: 32) mengungkapkan bahwa terdapat pengaruh dari blended learning yaitu pembelajaran blended learning mampu meningkatkan penguasaan konsep siswa. Penelitian dari Rabacal (2018), yaitu nilai rata-rata yang dicapai oleh kelas kontrol meningkat dari 19.35 sampai 21.93, sedangkan skor kelas eksperimen mengalami peningkatan rata-rata dari 19,05 menjadi 37,02 , artinya skor kelas eksperimen dan kelas kontrol mengalami peningkatan, namun kelas eksperimen mengalami peningkatan lebih tinggi dibandingkan dengan kelas kontrol, sehingga penerapan pembelajaran dengan blended learning efektif untuk meningkatkan penguasaan konsep siswa.

\section{PENUTUP}

Berdasarkan hasil penelitian dari pembahasan yang telah dilakukan, maka dapat disimpulkan Pembelajaran blended learning berbasis $L M S$ dengan model pembelajaran inkuiri memiliki pengaruh yang signifikan terhadap pengusaan konsep siswa dibandingkan pembelajaran konven-sional (metode ceramah). Hal ini dilihat dari nilai $F_{\text {hitung }}>F_{\text {tabel }}(15,45>3,98)$ maka $\mathrm{H}_{0}$ ditolak dan $\mathrm{H}_{1}$ diterima dan rata-rata nilai $N$-Gain pada kelas eksperimen lebih tinggi dibandingkan $\mathrm{N}$-Gain pada kelas kontrol $(0,84>0,70)$, sehingga blended learning berbasis LMS dengan model pembelajaran inkuiri lebih efektif untuk meningkatkan penguasaan konsep siswa.

Berdasarkan simpulan, maka saran yang diberikan oleh peneliti, yaitu pembelajaran blended learning berbasis $L M S$ dengan model pembelajaran inkuiri dapat dijadikan salah satu alternatif bagi guru sebagai upaya untuk meningkatkan penguasaan konsep siswa, pada penerapannya perlu diperhatikan penguasaan guru dengan baik dalam penggunaan media tersebut agar proses penyampaian materi kepada murid lebih mudah, serta agar kegiatan pembelajaran semakin bermakna sebaiknya siswa lebih dituntun kembali dalam proses pemecahan masalah.

\section{DAFTAR PUSTAKA}

Azizah, S, R., Suyatna, A., \& Wahyudi, I. (2017). Pengaruh Penggunaan E-Learning dengan Schoology terhadap Hasil Belajar Siswa. Jurnal Pembelajaran Fisika, 5 (2), 127-138.

Azizmalayeri, K., Jafari, E. M., Sharif, M., Asgari, M., \& Omidi, M. (2012). The impact of guided inquiry methods of teaching on the critical thinking of high school students. Journal of education and Practice, 3(10), 42-48.

Awodeyi, A. F., Akpan, E. T., \& Udo, I. J. (2014). Enhancing teaching and learning of mathematics: Adoption of blended learning pedagogy in University of Uyo. International Journal of Science and Research, 3(11), 40-45.

Bawaneh, S. S. (2011). The effects of blended learning approach on students' performance: Evidence from a computerized accounting course. Interdisciplinary Journal of Research in Business, 1(4), 43-50.

Bulan, S. N., Maharta, N., \& Ertikanto, C. (2015). Pengaruh Kemampuan Inkuiri terhadap Hasil Belajar Fisika Berbantuan Virtual Laboratory. Jurnal Pembe-lajaran Fisika. 3 (3): 109-122.

Ergul, R., Simsek, Y., Calis, S., Ozdilek, Z., Gomcmencelebi, S. \& Sanli, M. (2011). The Effect of Inquiry Based Science Teaching on Elementary School Students' Science Process Skills and Science Attitude. Bulgarian Journal of Science and Education Policy (BJSEP). 5 (1): 48-68.

Frydenberg, M. E., Andone, D. (2011). Learning for 21st Century Skills. IEEE's International Conference on Information Society, London, 27-29 June 2011, 314-318.

Hasanah, N., Suyanto, E., \& Suana, W. (2016). ELearning dengana Schoology Sebagai Suplemen Pembeajaran Fisika Materi Elastisitas dan Hukum Hooke. Jurnal Pembelajaran Fisika. 4(2): 71-81. 
Hermawanto., Kusairi, S., \& Wartono. (2013). Pengaruh Blended Learning terhadap Penguasaan Konsep dan Penalaran Fisika Peserta Didik Kelas X. Jurnal Pendidikan Fisika Indonesia. 9(1): 67-76.

King, S. E., \& Arnold, K. C. (2012). Blended learning environments in higher education: A case study of how professors make it happen. Mid-Western Educational Researcher, 25(1/2): 44-59.

Lin, Y.W., Tseng, C.L., \& Chiang, P.J. (2017). The Effect of Blended Learning in Mathematic Course. EURASIA Journal of Mathematics and Technology Education. 13 (3): 741770.

https://doi.org/10.12973/eurasia.2017.0064 $\underline{1 a}$

Lynch, R. \& Dembo, M. (2004). The Relationship between Self Regulation and Online Learning in a Blended Learning Context. International Review of Research in Open and Distance Learning, (online), 5 (2): 116 ,

http://www.irrodl.org/index.php/irrodl/article /view/189/799), diakses tanggal 6 Januari 2012.

Mahnegar, F. (2012). Learning Management System. International Journal of Business and Social Science. 3 (12): 144-150.

Sinuraya, J., \& Tarigan, R. (2012). Pengaruh Metode Inkuri Berbasis Blended Learning dan Kreativitas Belajar Terhadap Hasil Belajar Mahasiswa pada Mata Kuliah Fisika Umum I di FMIPA UNIMED. Jurnal Penelitian Bidang Pendidikan, 18(3), 72-80. https://doi.org/10.24114/jpp.v18i3.4285

Nazarenko, A. L. (2015). Blended learning vs traditional learning: What works? (a case study research). Procedia-Social and Behavioral Sciences. 200:77-82. https://doi.org/10.1016/i.sbspro.2015.08.01 $\underline{8}$

Novitayati, R. (2013). Pengaruh Metode Blended Learning dan Self Regulated Learning Terhadap Hasil Belajar Kognitif IPS. Jurnal Penelitian Kependidikan, (1), 48-57.

Putri, N. W. M. A., Jampel, I. N., \& Suartama, I. K. (2014). Pengembangan E-learning berbasis schoology pada mata pelajaran IPA kelas VIII SMP Negeri 1 Seririt. Jurnal Edutech. 2 (1): 1-11.
Rabacal, J. S. (2018). Blended Learning: Unveiling its Potential in One ASEAN Classroom Setting. Asia Pacific Journal of Multidisciplinary Research. 6 (3): 91-95.

Rovai, A. P., \& Jordan, H. (2004). Blended learning and sense of community: A comparative analysis with traditional and fully online graduate courses. The International Review of Research in Open and Distributed Learning, 5(2): 1-13. http://dx.doi.org/10.19173/irrodl.v5i2.192

Sakdiah, S., Mursal, M., \& Syukri, M. (2018). Penerapan Model Inkuiri Terbimbing Untuk Meningkatkan Pemahaman Konsep dan Kps Pada Materi Listrik Dinamis Siswa SMP. Jurnal IPA \& Pembelajaran IPA, 2(1), 41-49.

https://doi.org/10.24815/iipi.v2i1.10727

Sutisna, A. (2016). Pengembangan Model Pembelajaran Blended Learning pada Pendidikan Kesetaraan Program Paket C dalam Meningkatkan Kemandirian Belajar. Jurnal Teknologi Pendidikan, 18(3), 156-168.

Trilling, Bernie \& Fadel, Charles. (2009). 21st Century Skills: Learning for Life in Our Times. New jersey: John Wiley \& Sons.

Ummi, H. U., \& Mulyaningsih, I. (2016). Penerapan Teori Konstruktivistik pada Pembelajaran Bahasa Arab di Kelompok 28 Program Intensifikasi Bahasa Arab IAIN Syekh Nurjati Cirebon. Indonesian Language Education and Literature, 1(2), 162-172. http://dx.doi.org/10.24235/ileal.v1i2.600

Wicaksono, A., \& Roza, A. S. (2015). Teori Pemmbelajaran Bahasa: Suatu Catatan Singkat. Yogyakarta: Pernerbit Garudhawacana

Winanti, N, Y., Nyeneng, I. D. P., \& Suyatna, A. (2015). Pengaruh Model Pembelajara Inkuiri dengan Pendekatan Nilai Terhadap Hasil Belajar Fisika. Jurnal pembelajaran Fisika. 3 (3): 133-145 